\title{
Benzoquinone from $F$ usarium pigment inhibits the proliferation of estrogen receptor-positive MCF-7 cells through the NF-kB pathway via estrogen receptor signaling
}

\author{
LIXIANG ZHENG ${ }^{1,2}$, YUJIAN CAI $^{1}$, LI ZHOU ${ }^{3}$, PING HUANG $^{2}$, XIAOYING REN $^{2}$, \\ AIREN ZUO ${ }^{2}$, XIANMING MENG ${ }^{2}$, MINJUAN XU $^{2}$ and XIANGRU LIAO ${ }^{1}$ \\ ${ }^{1}$ College of Biology Engineering, Jiangnan University, Wuxi, Jiangsu 214122; ${ }^{2}$ School of Basic Medicine, and \\ ${ }^{3}$ School of Computer Science, Jiangxi University of Traditional Chinese Medicine, Nanchang, Jiangxi 330004, P.R. China
}

Received February 3, 2016; Accepted November 17, 2016

DOI: $10.3892 /$ ijmm.2016.2811

\begin{abstract}
Natural pigments are known for possessing a wide range of pharmacological and health-promoting properties. The pigments, produced by a new strain Fusarium (Fusarium sp. JN158) previously identified in our laboratory, were found to have 6 peaks (representing 6 compounds) by high-performance liquid chromatography with a diodearray detector (HPLC-DAD) separation. The 6th peak compound (compound VI) is a benzoquinone compound. In this study, we examined the effects of compound VI on the proliferation of breast cancer cells and aimed to elucidate the underlying mechamisms. Compound VI exerted antiproliferative effects on MCF-7 estrogen receptor $(\mathrm{ER})^{+}$cells in a dose-dependent manner $\left(\mathrm{IC}_{25}, 7 \mu \mathrm{M} ; \mathrm{IC}_{50}, 11 \mu \mathrm{M}\right)$, whereas it had no effect on MDA-MB-231 ER cells and normal cells. The cell index (CI) began to decrease at $24 \mathrm{~h}$ following treatment with benzoquinone. Mechanistically, the results from molecular analysis revealed that compound VI inhibited the expression of ER $\alpha$, progesterone receptor (PR), vascular endothelial growth factor (VEGF), Bcl-2, cyclin D1 and nuclear factor- $\mathrm{\kappa B}(\mathrm{NF}-\mathrm{\kappa B}) \mathrm{p} 65$, while it increased the expression of cleaved caspase-3 and Bax in the MCF-7 cells. Taken together, our findings indicate that compound VI exerts anti-proliferative effects on MCF-7 cells through the NF- $\mathrm{KB}$ pathway via the regulation of ER signaling. Our data may indicate that benzoquinone from Fusarium pigment may have potential for use as an anti-proliferative agent in the treatment of breast cancer.
\end{abstract}

Correspondence to: Professor Xiangru Liao, College of Biology Engineering, Jiangnan University, 1800 Lihu Road, Wuxi, Jiangsu 214122, P.R. China

E-mail: yjcai@jiangnan.edu.cn

Key words: Fusarium benzoquinone pigment, anti-proliferation, estrogen receptor signaling, nuclear factor- $\kappa \mathrm{B}$ pathway

\section{Introduction}

Natural pigments are known for possessing a wide range of pharmacological and health-promoting properties, including anti-bacterial, anti-viral, anticancer and antioxidant activities $(1,2)$. Increasing advances in medicinal chemistry have played key roles in transforming a class of dietary naturally produced pigments into potential medical therapeutics (3). Biosynthetic pigments are important natural pigments, not restricted by seasons, materials and other conditions. Microorganisms can undergo continuous fermentation to produce pigments to meet the increasing needs of the community, and the majority of microbial pigments have biological activities $(4,5)$.

Although microbial pigments have been extensively studied, fungal pigments remain less reported. Fungi are a common and important species, and are widely distributed, easy to be cultured, not requiring a rich amount of nutrients and having potent antiviral properties. In the past, much attention was paid to the hazards of Fusarium and to the toxins produced, but not on its usefulness $(1,2)$. We previously identified a new strain Fusarium (Fusarium sp. JN158) in our laboratory. This strain is capable of producing pigments. Following fermentation, the colors of the crude pigments varied due to the different $\mathrm{pH}$ levels. Under acidic conditions, the pigments were red in color, while under alkaline conditions, the pigments were purple in color and precipitated; they exhibited an antioxidant function and exerted inhibitory effects on the proliferation of cancer cells (6). The products were separated by highperformance liquid chromatography with a diode-array detector (HPLC-DAD) and exhibited 6 peaks (representing 6 compounds). The 6th peak representing the 6 th compound was the highest one and the distance between this peak with the surrounding peaks was the greatest. This component was separated and purified, the purity of which was $98 \%$. Based on the results of ${ }^{1} \mathrm{H}$ NMR and ${ }^{13} \mathrm{C}$ NMR spectrum analysis, the compound was determined to be a benzoquinone compound (one of the quinone compounds) (7,8) (Fig. 1).

Pre-screening of fungal pigment at various concentration using growth inhibition assays indicated that the pigments from fungus exhibited anti-cancer effects, inhibiting cancer 
cell proliferation (9). Thus, led us to select compound VI for further investigations using MCF-7 breast cancer cells. In the present study, we aimed to examine the effects of compound VI on the proliferation of MCF-7 estrogen receptor $(\mathrm{ER})^{+}$cells and on MDA-MB-231 ER' cells, and to further elucidate the underlying mechanisms. We demonstrated that ER is an important target for therapeutic strategies aimed at controlling the proliferation of hormone-dependent breast cancer cells. Of note, the activation of nuclear factor- $\kappa \mathrm{B}(\mathrm{NF}-\kappa \mathrm{B})$ may play a key role in $\mathrm{ER}^{+}$tumors. The constitutive activation of NF- $\mathrm{\kappa B}$ in breast tumors is associated with more aggressive $\mathrm{ER}^{+}$tumors. Recent data have indicated that the activity of NF- $\mathrm{KB}$ is associated with ER signaling in breast cancer cells (10-12).

The purpose of this study was to evaluate the anti-proliferative activity in both MCF-7 and MDA-MB-231 human breast cancer cell lines and the molecular mechanisms through which compound VI inhibits ER signaling in androgen-dependent MCF-7 cells.

\section{Materials and methods}

Reagents. Monoclonal antibodies against vascular endothelial growth factor (VEGF; sc-7269), caspase-3 (sc-7148), $\mathrm{ER} \alpha$ (sc-73562), progesterone receptor (PR; sc-130071), Bax (sc-20067), Bcl-2 (sc-130308), cyclin D1 (sc-70899) and NF-кB p65 (sc-372) were provided by Santa Cruz Biotechnology, Inc. (Santa Cruz, CA, USA). RPMI-1640 medium (Gibco-Invitrogen, Grand Island, NY, USA) was purchased from Shanghai Chemical Reagent Co. Ltd. (Shanghai, China). The tetrazolium salt 3-(4,5-dimethylthiazol-2-yl)2,5-diphenyltetrazolium bromide (MTT) was purchased from Sigma (Grand Island, NY, USA).

Cell lines. Pulmonary adenocarcinoma cells (A539), human gastric carcinoma cells (MKN-45), hepatocellular carcinoma cells (HepG2), human colon cancer cells (SW620), human umbilical vein endothelial cells (HUVECs) and human breast cancer cells [MCF-7 (ER $)$, MDA-MB-231 (ER)] were purchased from Shanghai Institutes for Biological Sciences, Chinese Academy of Sciences, Shanghai, China.

Cell viabilityand cellproliferation assay. The cells werecultured in complete Dulbecco's modified Eagle's medium (DMEM) medium containing $10 \%$ fetal bovine serum (FBS). The cells were cultured in 24-well plates at the concentration of 40,000 cells $/ \mathrm{ml}$. The pigment compound VI (benzoquinone) was diluted in acid-ethanol (the control groups were treated with an equal volume of acid-ethanol solution). The cells were then incubated at $37^{\circ} \mathrm{C}$ in a humidified atmosphere of $5 \% \mathrm{CO}_{2}$ for $24 \mathrm{~h}$. The cells were treated with $17 \beta$-estradiol $\left(\mathrm{E}_{2}, 0.1 \mu \mathrm{M}\right.$; Sigma-Aldrich, Castle Hill, NSW, Australia), fulvestrant (Fu, $0.13 \mu \mathrm{M}$; Sigma, Auckland, New Zealand), compound VI (5, 10 and $15 \mu \mathrm{M}$ ), or the corresponding control solutions. The cells were incubated at $37^{\circ} \mathrm{C}, 5 \% \mathrm{CO}_{2}$ in a humidified incubator for $24 \mathrm{~h}$. Assays were initiated by the addition of $100 \mu \mathrm{l}$ MTT solution $(2 \mathrm{mg} / \mathrm{ml})$ to each well and incubating the cells for an additional $4 \mathrm{~h}$ at $37^{\circ} \mathrm{C}$. Subsequently, the medium was removed and $1 \mathrm{ml}$ dimethylsulphoxide (DMSO) was added to each well. Finally, the supernatants were transferred to 96-well plates in triplicate, which were read at a wavelength of $490 \mathrm{~nm}$ with

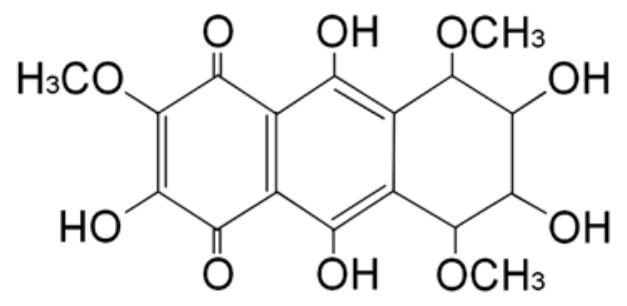

Figure 1. The structure of pigment compound VI.

a Thermo Scientific Multiskan ${ }^{\circledR}$ Spectrum spectrophotometer (Thermo Fisher Scientific, Inc., Waltham, MA, USA).

The pigment inhibitory concentration $\left(\mathrm{IC}_{50}\right.$, defined as the drug concentration at which cell growth was inhibited by $50 \%$ ) was assessed from the dose-response curves. The percentage viability of the pigment extract was calculated using the formula: cell viability $(\%)=100-\left[\left(\mathrm{OD}_{\text {pigment control }}\right)-\left(\mathrm{OD}_{\text {pigmen }}\right) /\right.$ $\left.\left(\mathrm{OD}_{\text {pigment }}\right)\right]$ x100.

Monitoring cell behavior in real-time. Cell behavior was monitored in real-time using the xCELLigence system E-Plate (ACEA Biosciences Inc., San Diego, CA, USA). A total of 20,000 MCF-7 cells was seeded in each well and fresh DMEM was added for a duration of $24 \mathrm{~h}$. The DMEM was then removed from these wells and medium containing compound IV at various concentrations ( $\mathrm{VI} \mathrm{IC}_{25}$, compound $\mathrm{VI} \mathrm{IC}_{25}$; VI IC ${ }_{75}$, compound $\mathrm{VI} \mathrm{IC}_{75}$ ) was then added. The impedance value of each well was automatically monitored by the xCELLigence system for a duration of $72 \mathrm{~h}$ and expressed as a cell index (CI) value. The $\mathrm{CI}$ value was used to represent the cell status based on the measured frequency-dependent electrical impedance. The CI value was used as a global guide to cellular behaviour including attachment, proliferation and spreading.

Immunohistochemistry assay. The cells were seeded onto glass coverslips placed in a 24 -well plate $\left(5 \times 10^{5}\right.$ cells/well $)$ in complete DMEM medium containing 10\% FBS and incubated overnight. The cells were treated with $\mathrm{VIIC}_{50}$, Fu or the respective controls or the vehicle. The VI IC 50 Con used was an equal volume of acid-ethanol solution. The fulvestrant control (Fu Con) used was an equal volume of acetate solution. Complete medium only was used as the vehicle. The cells were fixed using $4 \%$ paraformaldehyde, $0.15 \%$ picric acid in $1 \mathrm{X}$ phosphate-buffered saline (PBS) for $20 \mathrm{~min}$ at room temperature. The cells on glass coverslips were incubated with the indicated primary antibodies at room temperature for $1 \mathrm{~h}$. After washing 3 times with PBS for $5 \mathrm{~min}$, the slides were incubated for $15 \mathrm{~min}$ with the corresponding biotinylated secondary antibodies (Beijing Zhongshan Golden Bridge Biotechnology Co., Ltd., Beijing, China), followed by $30 \mathrm{~min}$ of incubation with streptavidinhorseradish peroxidase (DakoCytomation A/S, Glostrup, Denmark). Color was developed with 3'-diaminobenzidine (DAB) for 3-7 min. Counterstaining was performed with hematoxylin for $5 \mathrm{~min}$, and the slides were coverslipped. To evaluate ER $\alpha$ and PR expression, a semi-quantitative method was used to determine the reaction intensity and percentage of positive cells (deep blue) from 10 representative fields of the specimen at x100 magnification (Olympus DSX500, Olympus Corp., Tokyo, Japan).. 
A
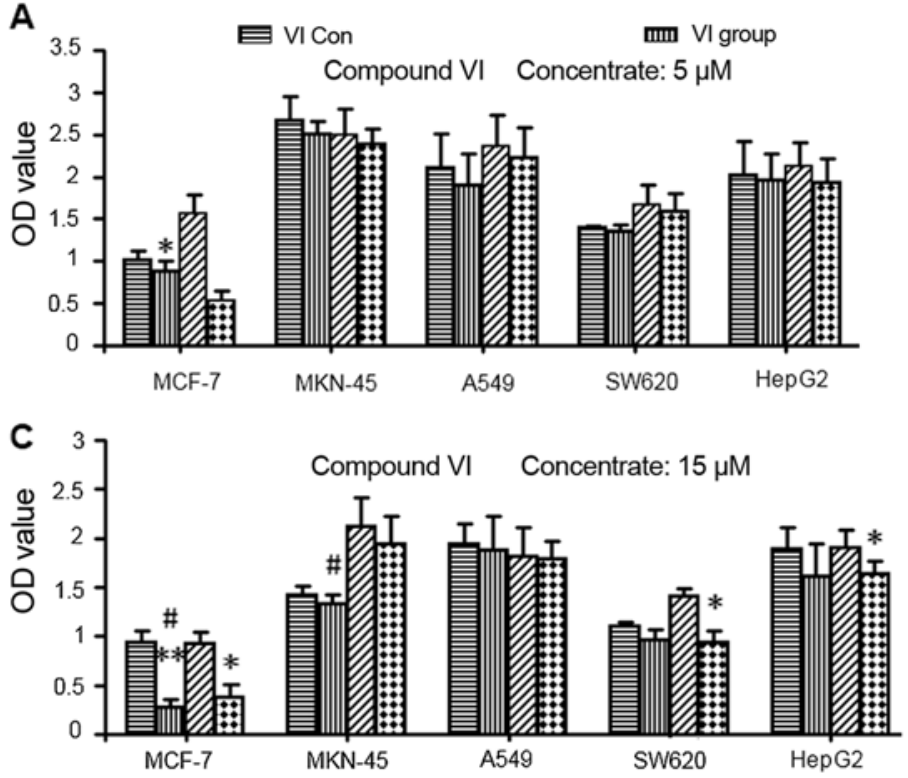
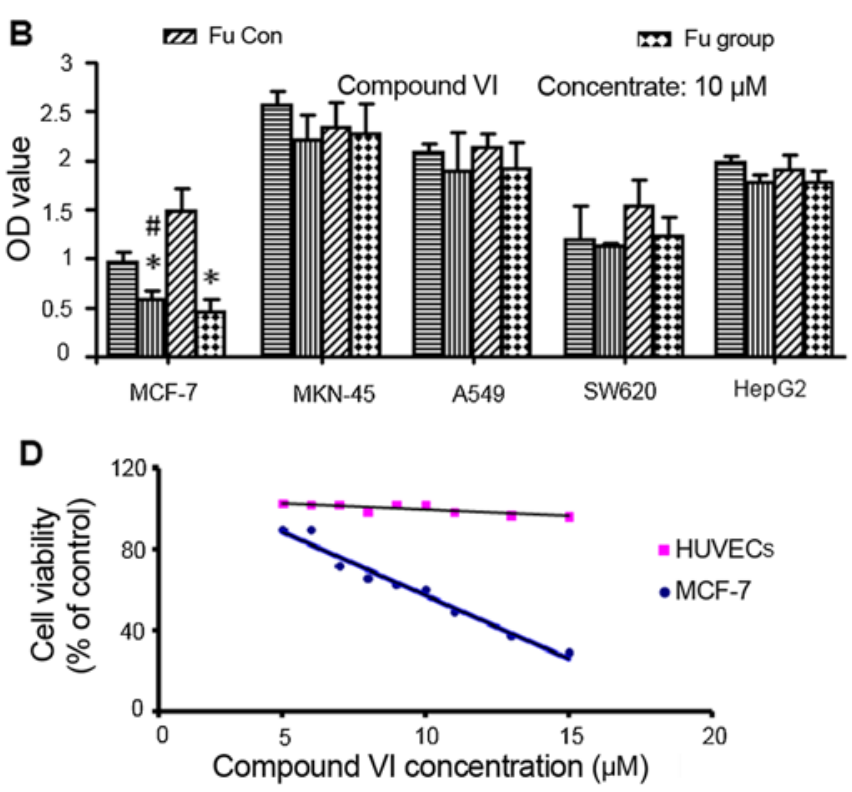

Figure 2. Effects of compound VI on the proliferation of A549, MCF-7, MKN-45, HepG2, SW620 cells or the viability of MCF-7 and human umbilical vein endothelial cells (HUVECs). (A-C) Cell proliferation was examined following treatment with compound VI at 5, 10 and $15 \mu \mathrm{M}$ for $24 \mathrm{~h}$, respectively. (D) Cell viability was examined following treatment with compound VI at 5, 6, 7, 8, 9, 10,11, 13 and $15 \mu$ M. Viability was determined by MTT assay. OD, optical density; $\mathrm{n}=20$ wells. ${ }^{*} \mathrm{p}<0.05$ vs. VI Con; ${ }^{* *} \mathrm{p}<0.01$ vs. VI Con; ${ }^{*} \mathrm{p}<0.05$ vs. fulvestrant $(\mathrm{Fu})$.

Immunofluorescence staining and confocal microscopy. This method was used to determine the expression of NF- $\mathrm{B}$ p65, caspase- 3 in MCF-7 cells. The cells were seeded onto glass coverslips placed in a 24 -well plate $\left(5 \times 10^{5}\right.$ cells/well). The groups and treatments were as described above. The cells were treated with various concentrations of the pigment compound VI. Following treatment, the cells were fixed with $4 \%$ paraformaldehyde for $15 \mathrm{~min}$ at room temperature. The cells were blocked with $10 \%$ normal goat serum (Gibco) prior to incubation with rabbit anti-NF- $\kappa$ B p65, caspase-3 (Santa Cruz Biotechnology, Inc.) or negative control rabbit IgG (Beijing Zhongshan Golden Bridge Biotechnology Co., Ltd.) overnight at $4^{\circ} \mathrm{C}$. After rinsing with PBS, the cells were incubated with goat anti-rabbit Cy5 (Abcam, Cambridge, MA, USA) and $1 \mu \mathrm{g} / \mathrm{ml}$ of Hoechst 33342 (Sigma) for $1 \mathrm{~h}$ at room temperature. Immunolabelling was visualized and imaged using an Olympus DP71 fluorescence microscope (Olympus, Center Valley, PA, USA).

Western blot analysis. The cells were washed twice with cold PBS and lysed in ice-cold RIPA buffer (Sigma) supplemented with complete mini-protease inhibitor cocktail tablet (Roche Diagnostics, Mannheim, Germany). The cell lysates were centrifugated at $4^{\circ} \mathrm{C}, 12,000 \mathrm{rmp}$, for $30 \mathrm{~min}$. We collected the supernatant and measured the protein concentration using a Bradford kit (Thermo Fisher Scientific, Inc.). Sodium dodecyl sulfate-polyacrylamide gel electrophoresis (SDS-PAGE) electrophoresis was carried out using standard protocols with $15 \mu \mathrm{g}$ of total protein/well. The primary antibodies used were as follows: mouse anti-human cyclin D1, VEGF, NF- $\kappa$ B p65, Bax and Bcl-2 monoclonal antibodies (1:200). Following incubation with the primary antibodies at $4^{\circ} \mathrm{C}$ overnight, the membranes were washed with PBST 3 times, and were then incubated with HRP-labeled secondary antibody (1:2,000; Beijing Zhongshan Golden Bridge Biotechnology Co., Ltd.) for $2 \mathrm{~h}$ at room temper- ature. The blots were visualized using a chemiluminescent detection kit (Thermo Fisher Scientific, Inc.). The gray ratio of each band was measured using ImageJ software. Relative protein expression was calculated using the following gray ratio: gray ratio = gray of target band $/ \beta$-actin gray.

Statistical analysis. SPSS 11.5 statistical software was used for data processing, and data are the means and standard deviation (means $\pm \mathrm{SD}$ ). Comparisons between 2 groups were made using the LSD test and Hochberg statistical methods for statistical processing. The value of $\alpha=0.05$ was used as a significant test standard, with a value of $\mathrm{P}<0.05$ used to indicate a statistically significant difference.

\section{Results}

Compound VI inhibits the proliferation of MCF-7 cells. MTT assay was used to screen the isolated compound VI against a panel of human cancer cell lines, including A549, MCF-7, MKN-45, HepG2 and SW620 cells. As shown in Fig. 2, the isolated compound VI displayed broad spectrum anti-proliferative activities in a dose-dependent manner (Fig. 2A). Compared with the corresponding controls, compound VI inhibited the proliferation of different tumor cells in a dose-dependent manner (Fig. 2A-C), while it did not have any apparent effect on normal cells, such as HUVECs (Fig. 2D). We also found that compound VI exerted a more potent inhibitory and significant effect on MCF-7 cell proliferation (Fig. 2A-C).

To further explore the correlation between the concentration of compound VI and its inhibitory effect on MCF-7 cells, we employed 9 gradients of compound VI. The results revealed that $7 \mu \mathrm{M}$ of compound VI exerted a $25 \%$ inhibition, while $11 \mu \mathrm{M}$ of compound VI exerted a $50 \%$ inhibition (Fig. 2D). Our findings further validated that compound VI exerts an 


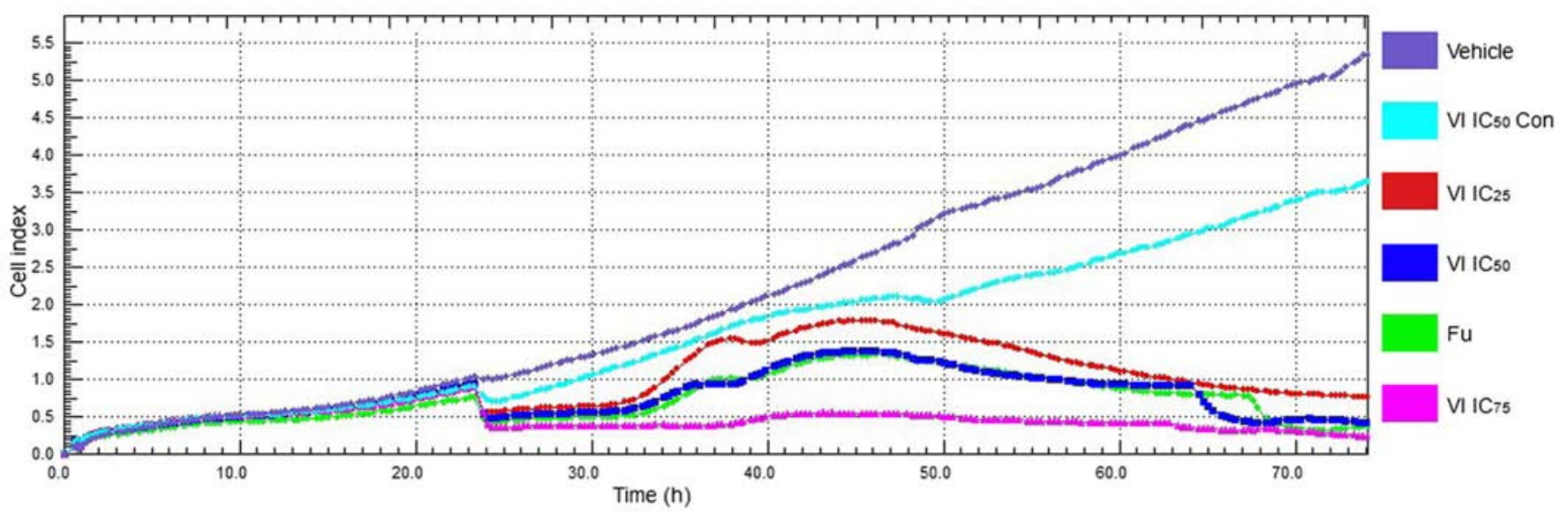

Figure 3. Effect of compound VI on the proliferation of MCF-7 cells. Cell proliferation was monitored in real-time using the xCELLigence system.

inhibitory effect on MCF-7 cell proliferation in a concentrationdependent manner.

Determination of the behavior of MCF-7 cells treated with compound VI by real-time cell analysis. The XCELLigence system is a label-free cell-based assay system, which integrates microelectronics and cell biology, and is suitable for the uninterrupted monitoring of the biological processes of living cells. The impedance measurements, which are displayed as CI values, provide quantitative information about the biological status of the cells including cell number, viability and morphology (13). In this study, we monitored the conditions of MCF-7 cells treated with compound VI at various concentrations using the real-time cell-based assay (RTCA) platform. The distinct patterns can be seen on the graph, which can be attributed to cell adhesion and cell proliferation (0-24 h) (Fig. 3).

After having determined the optimal conditions to study the behavior of the MCF-7 cells (data not shown), we then determined whether compound VI affects the behavior of MCF-7 cells. In order to accomplish this, the MCF-7 cells were seeded in DMEM containing various concentrations of compound VI. Cell behavior was monitored using RTCA over a period of $72 \mathrm{~h}$. The results revealed that the CI value of MCF-7 cells was robust and did not exhibit any detectable difference within DMEM medium or without compound VI treatment from 0 to $24 \mathrm{~h}$ (Fig. 3). However, cell proliferation was significantly compromised with compound VI treatment from 24 to 72 h (Fig. 3). As shown in Fig. 3, the cells in the vehicle-treated group continuously grew more rapidly (dark purple line); however, cells in the treated group grew at a slower rate during the period of 24-48 $\mathrm{h}$. The CI value of the treatment groups was the hightest at $46 \mathrm{~h}$. After this time point, the $\mathrm{CI}$ values of the treated cells gradually decreased $\left[\mathrm{VI} \mathrm{IC}_{25}\right.$ (red line), VI IC (dark blue line), $\mathrm{Fu}$ (green line) and VI IC $_{75}$ (light purple line)], while the cells in the $\mathrm{VI} \mathrm{IC}_{50}$ control group grew more rapidly [Fig. 3, cyan (light blue) line]. Taken together, this observation suggests that compound VI exerts an inhibitory effect on MCF-7 cell proliferation, and these inhibitory effects are evident when cells are treated for a period $>24 \mathrm{~h}$.

Compound VI treatment decreases the expression of ER $\alpha$ and $P R$ in MCF-7 cells. ER signaling is the most attractive target for the clinical therapy of $\mathrm{ER}^{+}$breast cancer. Within the antiproliferative environment, there is compelling evidence to indicate that, in estrogen-sensitive human breast cancer cell lines, such as MCF-7, treatment with certain agents disrupts estrogen-responsive gene expression and inhibits estrogendependent proliferation. PR expression is traditionally used as a clinical indicator of ER function (that is, PR is an ER target gene) (14).

In this study, to determine whether the compound affects the expression of ER $\alpha$ and PR in MCF-7 cells, we employed immunohistochemisty staining assay. Compound VI was added at the $\mathrm{IC}_{50}$ concentration to the MCF-7 cells for $24 \mathrm{~h}$. The number of MCF-7 cells whose cytoplasm was stained deep blue represented the cells expressing ER $\alpha$ and PR. Immunohistochemical analysis demonstrated that the expression of ER $\alpha$ and PR was markedly inhibited in the cells treated with compound VI at the $\mathrm{IC}_{50}$ concentration (compare Fig. $4 \mathrm{~A}$ or B, VI IC ${ }_{50}$ to Fig. 4, VI IC 50 Con).

Compound VI differentially regulates the viability of $E R^{+}$ and ER breast cancer cells. The effects of the benzoquinone compound on cell viability were evaluated by MTT assay in ER $^{+}$MCF-7 and ER ${ }^{-}$MDA-MB-231 cells (Fig. 1A). Compared to the controls, compound VI exerted an overall decrease in the OD value in a dose-dependent manner. The compound, however, had no effect on MDA-MB-231 cells, suggesting that the anti-proliferative effects of compound VI are dependent on the presence of ER $\alpha$ (Fig. 5).

Caspase-3 and NF- $\kappa B$ immunofluorescence staining. Of note, the activation of the pro-inflammatory transcription factor, $\mathrm{NF}-\kappa \mathrm{B}$, may play a key role in $\mathrm{ER}^{+}$tumors, while caspases-3 plays an essential role in cell apoptosis and has been termed an 'executioner' protein for its role in cell apoptosis and may be used as a biomaker to predict tumor response to treatment (15). Quinone has been shown to induce the apoptosis of tumor cells by suppressing NF- $\mathrm{kB}$, activating the Akt pathway and suppressing tumor angiogenesis (16). Thus, in this study, we wished to determine whether compound VI affects the expression of NF- $\kappa \mathrm{B}$ and caspases-3. The results of immunofluorescence staining revealed that caspase- 3 was exclusively localized in the cytoplasm of MCF-7 cells (Fig. 6A, vehicle) 
A
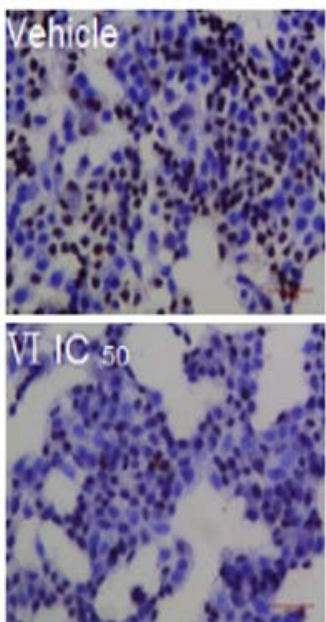

B
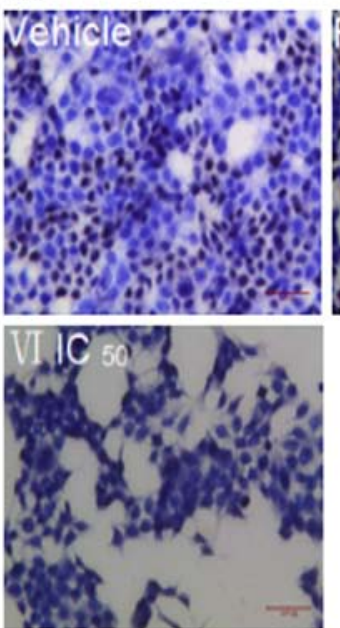
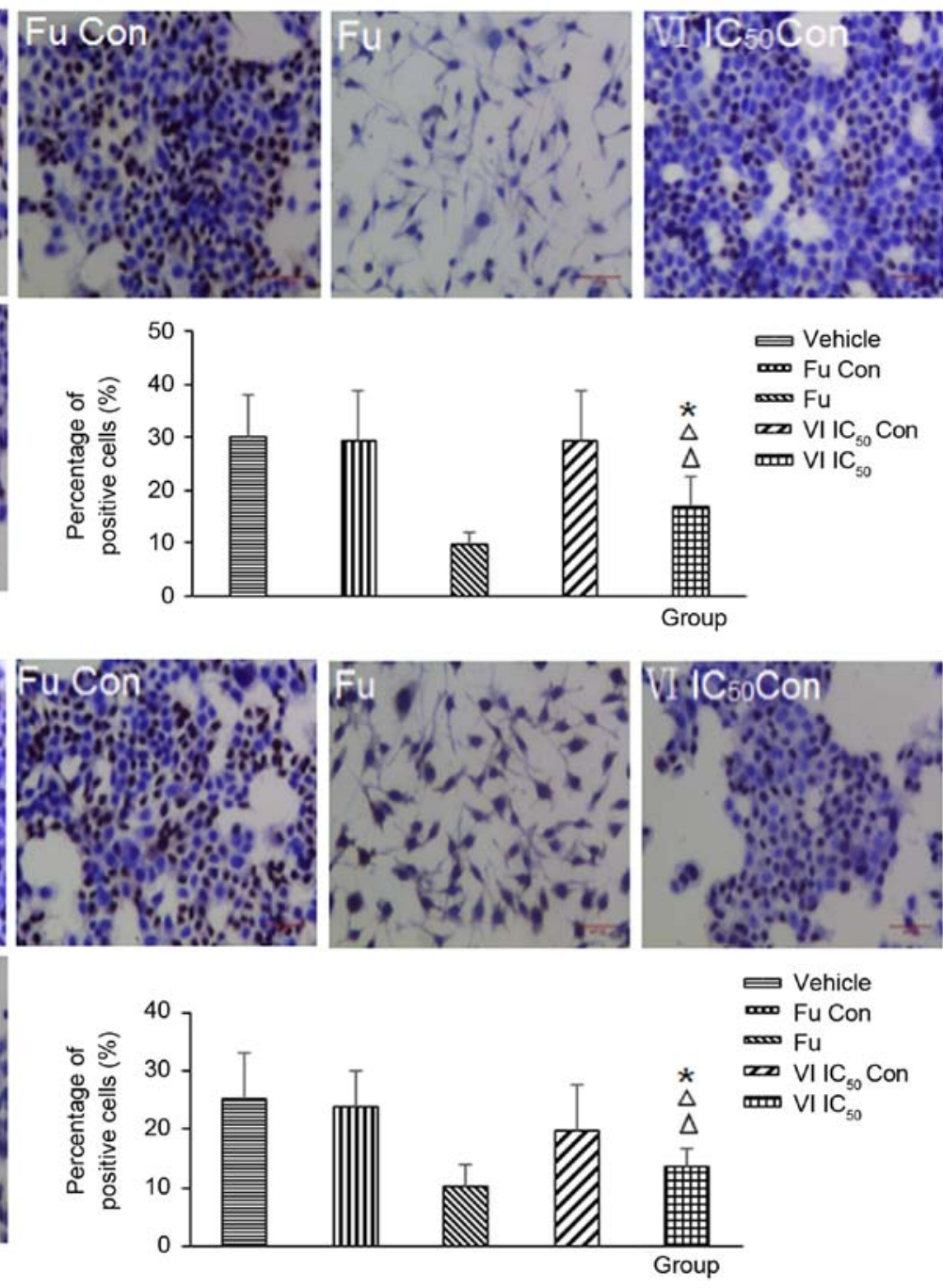

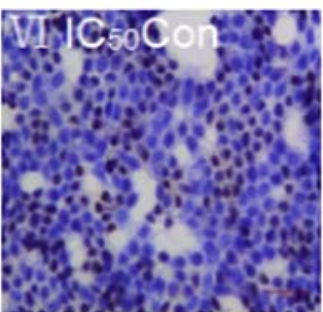

『Vhicle

w Fu Con

$\infty \mathrm{Fu}$

mIII VI $\mathrm{IC}_{50}$
CI IC $\mathrm{C}_{50}$ Con

\section{Vehicle}

mu Con

$\infty \mathrm{Fu}$

$\mathrm{VIIC}$ Con

피미 $\mathrm{VIIC}_{50}$

Group

Figure 4. Effect of compound VI on estrogen receptor- $\alpha(\mathrm{ER} \alpha)$ and progesterone receptor (PR) expression in MCF-7 cells. (A) ER $\alpha$ and (B) PR expression was

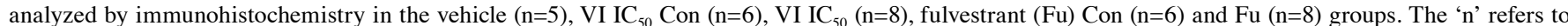
the number of wells. Values are the positive cells and are the means \pm SD. Magnification, x100; scale bar, $50 \mu \mathrm{m}$. ${ }^{*} \mathrm{p}<0.05 \mathrm{vs}$. VI IC ${ }_{50}$ Con; ${ }^{\triangle} \mathrm{p}<0.01 \mathrm{vs}$. vehicle.

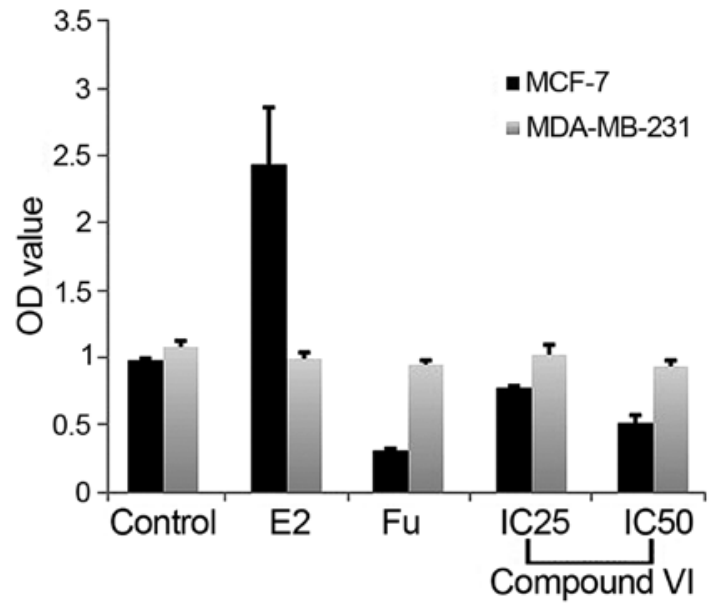

Figure 5. Differential treatment effects on MCF-7 (ER+) and MDA-MB-231 (ER-) cell viability. Cells were grown for $24 \mathrm{~h}$ in the absence and presence of $\mathrm{E}_{2}$, fulvestrant $(\mathrm{Fu})$, compound $\mathrm{VI}\left(\mathrm{IC}_{25}\right.$ and $\left.\mathrm{IC}_{50}\right)$. The data presented are the means \pm SD of triplicate wells $(n=3)$. while NF- $\mathrm{KB}$ was observed in the nuclei of MCF-7 cells (Fig. 6B, vehicle). We further explored the changes in the expression of NF- $\mathrm{kB}$ and caspase-3 following treatment of the cells with compound VI (VI IC 25 and VI IC ${ }_{50}$ ) for $24 \mathrm{~h}$. We observed that the expression of NF- $\mathrm{kB}$ was decreased (Fig. 6B), whereas that of caspase-3 was increased in the MCF-7 cells following treatment with compound VI (Fig. 6A). To further evaluate NF- $\kappa \mathrm{B}$ expression and cleaved caspase-3 activation, their protein levels were examined in the cells by western blot analysis (Fig. 7). Treatment with compound VI inhibited $\mathrm{NF}-\kappa \mathrm{B}$ expression and increased the cleavage of caspase-3.

Effect of compound VI on Bax, Bcl-2, NF- $\kappa B$ p65, caspase-3, $V E G F$ and cyclin D1 expression. To further explore the molecular mechanisms responsible for the inhibitory effects of compound VI on MCF-7 cell proliferation, we examined the protein expression of Bax, Bcl-2, NF-kB p65, caspase-3, VEGF and cyclin D1 by western blot analysis. The results revealed that following treatment with compound $\mathrm{VI}$ at $\mathrm{IC}_{25}$ and $\mathrm{IC}_{50}$ 

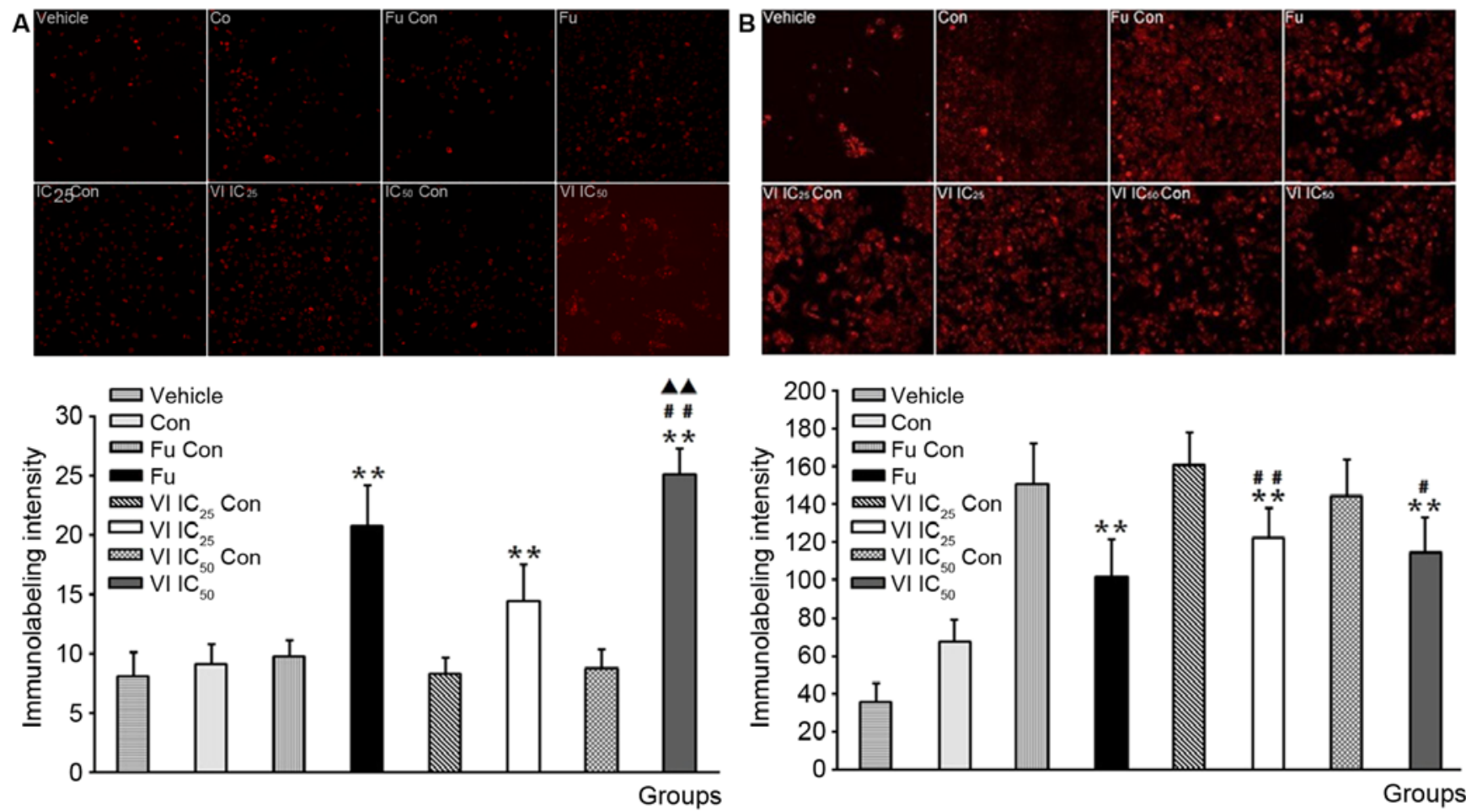

Figure 6. Subcellular localization of caspase-3 and nuclear factor- $\kappa \mathrm{B}(\mathrm{NF}-\kappa \mathrm{B})$ in $\mathrm{MCF}-7$ cells treated with compound VI ( $\mathrm{IC}_{25}$ and $\mathrm{IC}_{50}$ ) for $24 \mathrm{~h}$ examined by confocal microscopy. Immunofluorescence staining of (A) caspase-3 and (B) NF- $\kappa \mathrm{B}$ revealed cytoplasmic or nuclei localization in the cells, respectively. Treatment with compound VI had a a significant effect on the subcellular localization of caspase-3 and NF- $\kappa \mathrm{B}$ in $\mathrm{MCF}-7$ cells. ${ }^{* *} \mathrm{p}<0.01 \mathrm{vs}$. VI IC ${ }_{50}$ or $\mathrm{IC}_{25} \mathrm{Con}$; ${ }^{\#} \mathrm{p}<0.05$ or ${ }^{\# \#} \mathrm{p}<0.01$ vs. fulvestrant $(\mathrm{Fu})$.

for $24 \mathrm{~h}$, the levels of Bax and cleaved caspase-3 markedly increased compared to those of control group ( $\mathrm{p}<0.01$; Fig. 7 ). By contrast, the levels of Bcl-2, NF- $\mathrm{B}$, cyclin D1 and VEGF in the cells treated with compound VI at $\mathrm{IC}_{50}$ for $24 \mathrm{~h}$ were significantly lower than those of the control group ( $<<0.01$; Fig. 7). However, the levels of cleaved caspase- 3 and Bax in the cells treated with compound VI at $\mathrm{IC}_{50}$ were markedly higher than those of the control group ( $p<0.01$; Fig. 7B).

\section{Discussion}

Breast cancer is one of the most common malignancies affecting women worldwide and the second leading cause of cancer-related mortality in women (17). Surgical interventions and chemotherapy are able to significantly reduce mortality; however, both of these interventions have several limitations such as potential toxicity, severe side-effects and resistance to anti-estrogen compounds (18). Thus, new approaches to combat this neoplasm are required, also taking into account the new compounds that they may be used to prevent cancer.

Many of the natural products/secondary metabolites with interesting biological properties are considered as potentially important sources of novel bioactive anticancer compounds and are capable of producing chemically diverse compounds without any side-effects or with less side-efffects for a variety of clinical applications (19). Among the natural substances, quinone pigments (found in bacteria, fungi, animals and plants) have attracted attention in recent years due to both their importance in vital biochemical processes and their several known biological activities, such as antitumor, anti-bacterial and anti-viral effects $(20,21)$. In the present study, the new pigments, produced by Fusarium sp. JN158, were shown to exert anti-proliferative effects on cancer cells (Fig. 2); however, the biological functions of the pigment compound are largely unknown.

Pigment compounds have been shown to have potent antiproliferative activity against human colon cancer Caco-2 cells and $\mathrm{ER}^{+}$human breast cancer cell lines (18). In this study, The pigment compound VI inhibited the proliferation of different cancer cell lines in a concentration-dependent manner, but the MCF-7 (ER $)$ cell line was found to be more sensitive to compound VI. Compound VI did not affect the proliferation of the triple-negative (MDA-MB-231) human breast cancer cell line, following incubatoin for $24 \mathrm{~h}$, as shown by MTT assay. The reduction in the percentage of MCF-7 cell viability revealed that the bioactive compound VI exerted anti-proliferation effects at various concentrations. The results were in accordance with those of the xCELLigence RTCA platform assay; the CI value of the MCF-7 cells gradually decreased after $24 \mathrm{~h}$ of treatment with compound VI. Of note, compound VI significantly suppressed ER $\alpha$ and PR expression in MCF-7 cells. ER $\alpha$ plays a key role in the development of estrogen-dominant breast cancer. The majority of $\mathrm{ER}^{+}$primary tumors depend on estrogen signaling for their growth and survival (22). ER $\alpha$ and $\operatorname{ER} \beta$, members of the nuclear receptor superfamily, are structurally similar with slight differences in their ligand binding domains. Thus, the receptors can be modulated by ligands that are structurally similar to the endogenous ligand $17 \beta$-estradiol $\left(\mathrm{E}_{2}\right)(23)$. We hypothesized that treatment with compound VI may inhibit estrogen signaling in MCF-7 cells to block cell proliferation. 
A
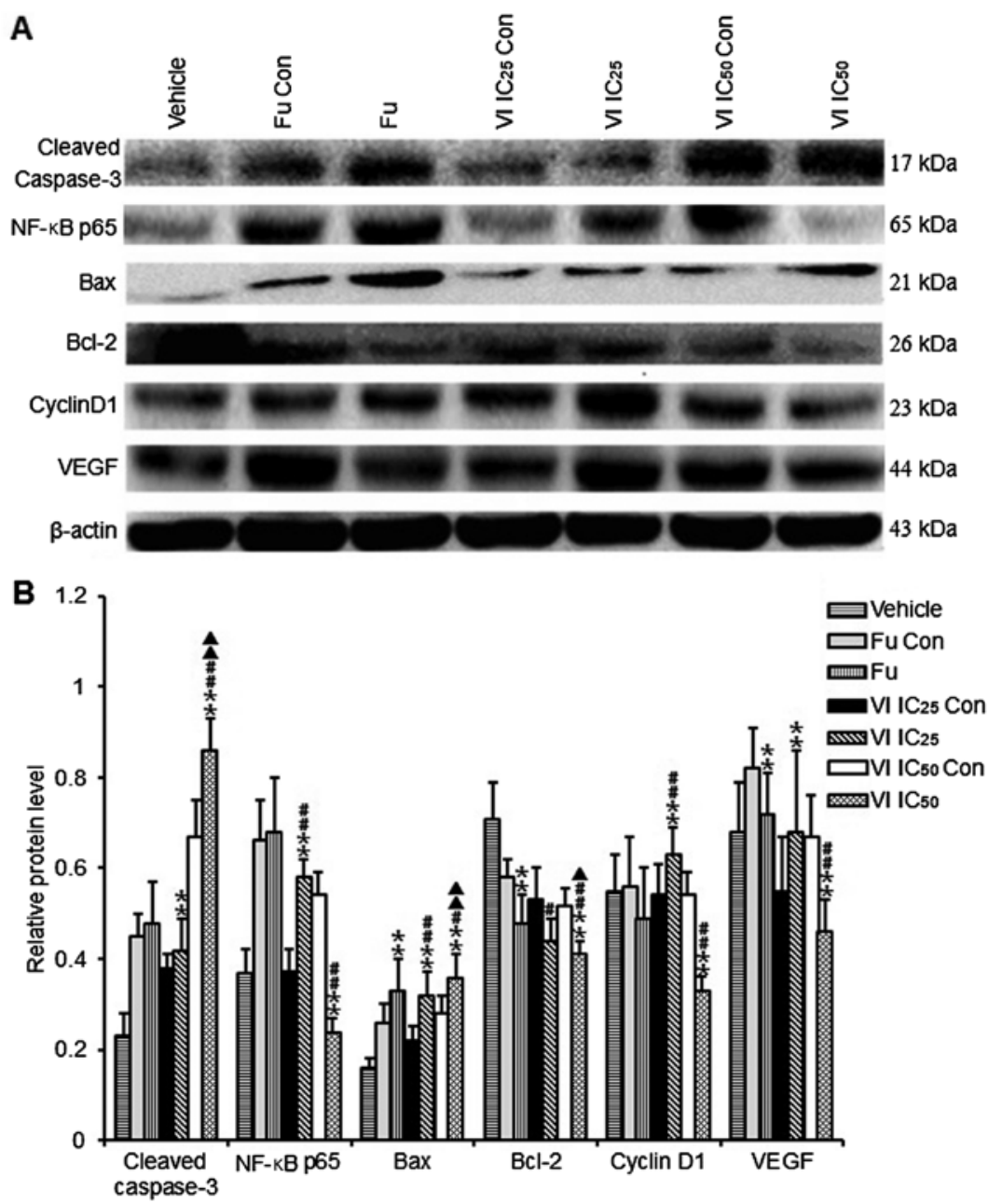

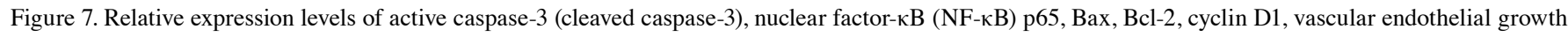
factor (VEGF) in MCF-7 cells. The cells were treated with compound $\mathrm{VI}\left(\mathrm{IC}_{25}\right.$ and $\left.\mathrm{IC}_{50}\right)$ for $24 \mathrm{~h}$. (A) The western blot bands of Bax, Bcl-2, cleaved caspase-3, cyclin D1, NF- $\mathrm{kB}$ p65, VEGF. (B) Densitometric analysis was performed to quantify the expression levels of the detected proteins. Data represent the means \pm SD of 7 independent experiments. ${ }^{* *} \mathrm{p}<0.01$ vs. VI IC $\mathrm{IC}_{25}$ Con or $\mathrm{IC}_{50}$ Con; ${ }^{\#} \mathrm{p}<0.05$ or ${ }^{\# \#} \mathrm{p}<0.01$ vs. fulvestrant $(\mathrm{Fu}) ;{ }^{\wedge} \mathrm{p}<0.05$ or ${ }^{\wedge} \mathrm{p}<0.01 \mathrm{vs}$. VI IC 25 .

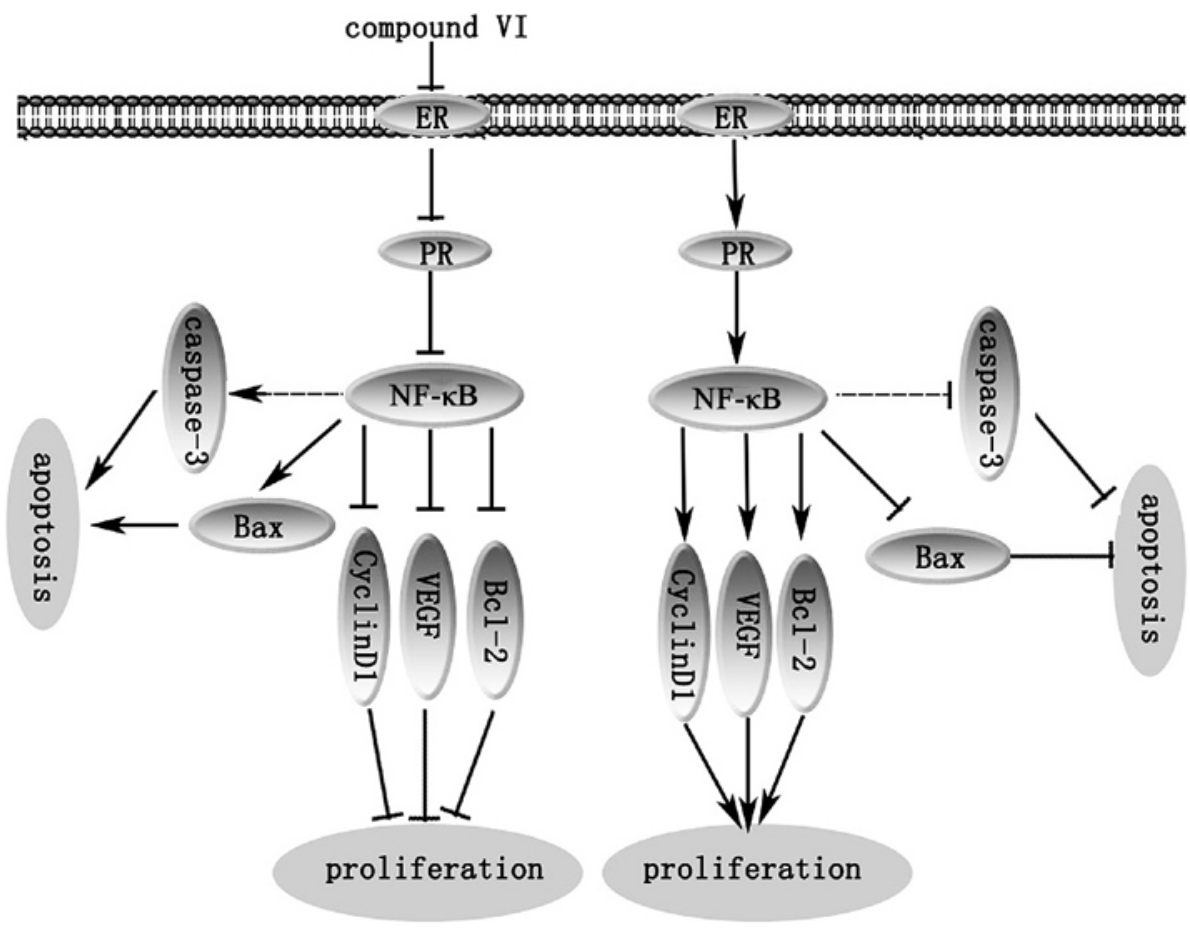

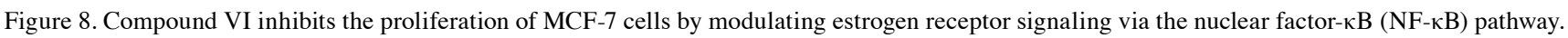


Indeed, compound VI inhibited the proliferation/or induced the apoptosis of MCF-7 cells by suppressing ER $\alpha$ expression and estrogen signaling.

ER and PR are highly expressed in MCF-7 cells, and significantly correlate with NF- $\mathrm{BB}$ expression in breast cancer. The constitutive activation of the NF- $\kappa \mathrm{B}$ pathway has been reported to be involved in cellular proliferation, the inhibition of apoptosis and the promotion of angiogenesis, and serves as an important component for resistance to therapy in breast cancer (24-27). NF- $\kappa \mathrm{B}$ can then upregulate the transcription of its target genes. It is noteworthy to mention that the reduced expression of NF- $\kappa \mathrm{B}$ suppresses the expression of downstream target genes involved in tumor cell proliferation. Therefore, it was speculated that compound VI may block the expression of $\mathrm{NF}-\kappa \mathrm{B}$ through the inactivation of $\mathrm{NF}-\kappa \mathrm{B}$ in breast cancer cells, and may inhibit the expression of downstream target genes, including cyclin D1, VEGF and Bcl-2 (24-27). It seemed that the inhibitory effect on $\mathrm{NF}-\kappa \mathrm{B}$ accounted for the anti-proliferative effects of compound VI. Furthermore, the perturbation of the protein expression levels of Bax and Bcl-2 is an important factor to determine the susceptibility of tumor cells to anticancer agents (24-27). Therefore, the anticancer pigment compound with the ability to suppress $\mathrm{NF}-\kappa \mathrm{B}$ translocation may be effective in inducing the apoptosis of cancer cells. Thus, compound VI suppresses the proliferation of MCF-7 cells by suppressing NF- $\kappa \mathrm{B}$ (Fig. 8).

In the present study, we identified the effectiveness of pigment compound VI as an anti-proliferative agent in MCF-7 cells, expanding its potential therapeutic utility for the treatment of human cancers. This pigment compound may be particularly advantageous when considering that severe side-effects are often a limiting factor for the use of chemotherapeutic drugs in the treatment of breast cancer.

\section{Acknowledgements}

This study was supported by the Chinese National Natural Science Fundation (grant no. 81160531), the Jiangxi Natural Science Fundation (grant no. 20161BAB205223), the Jiangxi Department of Education (grant no. GJJ10528).

\section{References}

1. Mata-Gómez LC, Montañez JC, Méndez-Zavala A and Aguilar CN: Biotechnological production of carotenoids by yeasts: An overview. Microb Cell Fact 13: 12, 2014.

2. Jackson H, Braun CL and Ernst H: The chemistry of novel xanthophyll carotenoids. Am J Cardiol 101: 50D-57D, 2008.

3. Kang B, Zhang X, Wu Z, Wang Z and Park S: Production of citrinin-free Monascus pigments by submerged culture at low $\mathrm{pH}$ Enzyme Microb Technol 55: 50-57, 2014.

4. Jomova K and Valko M: Health protective effects of carotenoids and their interactions with other biological antioxidants. Eur J Med Chem 70: 102-110, 2013.

5. Hu W, Gao Q, Hamada MS, Dawood DH, Zheng J, Chen Y and Ma Z: Potential of pseudomonas chlororaphis subsp. aurantiaca strain Pcho10 as a biocontrol agent against Fusarium graminearum. Phytopathology 104: 1289-1297, 2014.

6. Zeng XL, Cai YJ, Liao XR, Zeng XK, Li ZH and Zhang DB: Extraction and physico-chemical properties of pigments from liquid-cultured mycelia of Fusarium sp. B158. Food Science 33: 131-135, 2012 (In Chinese).

7. Reigan P, David S, Guo WC and Ross D: A mechanistic and structural analysis of the inhibition of the $90-\mathrm{kDa}$ heat shock protein by the benzoquinone and hydroquinone ansamycins. Mol Pharmacol 79: 823-832, 2011.
8. Pedrini N, Ortiz-Urquiza A, Huarte-Bonnet C, Fan Y, Juárez MP and Keyhani NO: Tenebrionid secretions and a fungal benzoquinone oxidoreductase form competing components of an arms race between a host and pathogen. Proc Natl Acad Sci USA 112: 231-240, 2015.

9. Gaascht F, Dicato M and Diederich M: Venus flytrap (Dionaea muscipula Solander ex Ellis) contains powerful compounds that prevent and cure cancer. Front Oncol. 3: 202-210, 2013.

10. Boopalan T, Arumugam A, Parada J, Saltzstein E and Lakshmanaswamy R: Receptor activator for nuclear factor $-\kappa B$ ligand signaling promotes progesterone-mediated estrogeninduced mammary carcinogenesis. Cancer Sci 106: 25-33, 2015.

11. King AE, Collins F, Klonisch T, Sallenave JM, Critchley HO and Saunders PT: An additive interaction between the NFkappaB and estrogen receptor signalling pathways in human endometrial epithelial cells. Hum Reprod 25: 510-518, 2010.

12. Ashcroft KJ, Syed F and Bayat A: Site-specific keloid fibroblasts alter the behaviour of normal skin and normal scar fibroblasts through paracrine signalling. PLoS One 8: e75600, 2013.

13. Kim JH, Jekarl DW, Kim M, Oh EJ, Kim Y, Park IY and Shin JC: Effects of ECM protein mimetics on adhesion and proliferation of chorion derived mesenchymal stem cells. Int J Med Sci 11: 298-308, 2014.

14. Marconett CN, Sundar SN, Poindexter KM, Stueve TR, Bjeldanes LF and Firestone GL: Indole-3-Carbinol triggers aryl hydrocarbon receptor-dependent estrogen receptor (ER) $\alpha$ protein degradation in breast cancer cells disrupting an ER $\alpha$-GATA3 transcriptional cross-regulatory loop. Mol Biol Cell 21: 1166-1177, 2010.

15. Mezzanotte L, An N, Mol IM, Löwik CW and Kaijzel EL: A new multicolor bioluminescence imaging platform to investigate NF- $\kappa \mathrm{B}$ activity and apoptosis in human breast cancer cells. PLoS One 9: e85550, 2014.

16. Tozawa K, Sagawa M and Kizaki M: Quinone methide tripterine, celastrol, induces apoptosis in human myeloma cells via NF- $\mathrm{KB}$ pathway. Int J Oncol 39: 1117-1122, 2011.

17. Kruk J: Overweight, obesity, oxidative stress and the risk of breast cancer. Asian Pac J Cancer Prev 15: 9579-9586, 2014.

18. Schiavano GF, De Santi M, Brandi G, Fanelli M, Bucchini A, Giamperi L and Giomaro G: Inhibition of breast cancer cell proliferation and in vitro tumorigenesis by a new red apple cultivar. PLoS One 10: e0135840, 2015.

19. Ahmadian M and Samah AA: Application of health behavior theories to breast cancer screening among Asian women. Asian Pac J Cancer Prev 14: 4005-4013, 2013.

20. Gordaliza M: Synthetic strategies to terpene quinones/hydroquinones. Mar Drugs 10: 358-402, 2012.

21. Bertanha CS, Januário AH, Alvarenga TA, Pimenta LP, Silva ML, Cunha WR and Pauletti PM: Quinone and hydroquinone metabolites from the ascidians of the genus Aplidium. Mar Drugs 12: 3608-3633, 2014.

22. Magnani L, Ballantyne EB, Zhang X and Lupien M: PBX1 genomic pioneer function drives ER $\alpha$ signaling underlying progression in breast cancer. PLoS Genet 7: e1002368, 2011.

23. Shanle EK and $\mathrm{Xu} \mathrm{W}$ : Endocrine disrupting chemicals targeting estrogen receptor signaling: Identification and mechanisms of action. Chem Res Toxicol 24: 6-19, 2011.

24. Condon JC, Hardy DB, Kovaric K and Mendelson CR: Up-regulation of the progesterone receptor (PR)-C isoform in laboring myometrium by activation of nuclear factor-kappaB may contribute to the onset of labor through inhibition of PR function. Mol Endocrinol 20: 764-775, 2006.

25. Dai XL,Zhou SL, Qiu J, Liu YF and Hua H: Correlated expression of Fas, NF-kappaB, and VEGF-C in infiltrating ductal carcinoma of the breast. Eur J Gynaecol Oncol 33: 633-639, 2012.

26. Reuter S, Prasad S, Phromnoi K, Ravindran J, Sung B, Yadav VR, Kannappan R, Chaturvedi MM and Aggarwal BB: Thiocolchicoside exhibits anticancer effects through downregulation of NF- $\mathrm{KB}$ pathway and its regulated gene products linked to inflammation and cancer. Cancer Prev Res (Phila) 3: 1462-1472, 2010.

27. Susanne C: Miller, Huang RL, Sakamuru S: Identification of known drugs that act as inhibitors of NF- $\mathrm{\kappa B}$ signaling and their mechanism of action. Biochem Pharmacol 9: 1272-1280, 2010. 